Наливайко А. Д., канд. техн. наук, доцент ${ }^{1}$ (ORCID 0000-0002-0675-9603); Поляєв А. I. ${ }^{1}$ (ORCID 0000-0002-6710-5144); Наливайко Л. П. ${ }^{2}$ (ORCID 0000-0001-9214-1713);

1 - Центр воєнно-стратегічних досліджень Національного університету оборони України імені Івана Черняховського, Київ;

2 - Науково-методичний центр організації наукової та науково-технічної діяльності Національного університету оборони України імені Івана Черняховського, Київ

\title{
Теоретичні основи побудови функціональної моделі процесу оборонного планування складових сил оборони
}

Резюме. У статті на основі аналізу процедур процесу оборонного планування складових сил оборони, у контексті перспектив розвитку національного оборонного планування розглянуті теоретичні основи побудови функціональної моделі процесу оборонного планування 3 урахуванням методів планування, які застосовуються у державах-членах НАТО.

Ключові слова: оборонне планування на основі спроможностей; процедури оборонного планування; модель оборонного планування.

Постановка проблеми. Удосконалення національного оборонного планування, як свідчить аналіз його історичного розвитку, спрямоване на досягнення рівня кращих світових практик.

Важливим питанням оборонного планування $\epsilon$ вибір і визначення основних аспектів побудови функціональної моделі процесу оборонного планування складових сил оборони (СО). Адже саме відповідність перспективної функціональної моделі оборонного планування сучасним принципам $\mathrm{i}$ підходам, які характерні для держав-членів НАТО, i ïx адаптація до національних особливостей робить систему планування гнучкою і ефективнішою.

Для досягнення необхідної гнучкості, така модель має включати, крім вже визначених діючими нормативно-правовими актами, такі процедури, як оцінювання спроможностей, оцінювання i управління ризиками, внесення змін i коригування відповідних оборонних документів під час їх виконання, бюджетного планування тощо. Така функціональна модель має забезпечити підвищення ефективності планування розвитку складових СО.

Ступінь розробленості проблеми. 3 введенням і подальшим розвитком системи оборонного планування в оборонному відомстві значна увага приділялась удосконаленню правового та методичного забезпечення. Особливої динаміки цей процес набув останніми роками в умовах впровадження новаторських підходів до втілення в діяльність органів військового управління сучасних методів планування, що особливо стосується методу планування на основі спроможностей [1-4]. Цій проблематиці також присвячена низка наукових досліджень, зокрема праці I. Руснака, Р. Тимошенка, Н. Дєнєжкіна, В. Корендовича, П. Крикуна, Ф. Саганюка та інших [5-9].

У цих публікаціях аналізуються підходи та методи оборонного планування, 3 урахуванням спрямованості України на подальшу євроатлантичну інтеграцію. Водночас, у них недостатньо уваги приділяється питанням розроблення методичної бази оборонного планування, як єдиного процесу; побудові моделі, яка б системно поєднувала процедури довгострокового, середньострокового, короткострокового і бюджетного планування.

Метою статті є систематизація підходів щодо визначення основних аспектів побудови функціональної моделі процесу оборонного планування на основі спроможностей складових сил оборони 3 урахуванням принципів планування, які характерні для країн Альянсу.

Виклад основного матеріалу. Сучасне оборонне планування, в рамках його подальшого розвитку в оборонному відомстві та поширенням на сили оборони України загалом набуває значного ускладнення щодо здійснення його процедур, які пов'язані зі складнощами аналітичного процесу оцінювання спроможностей та впровадження ефективного ресурсного менеджменту під час забезпечення досягнення цілей збалансованого ïx розвитку. Ці та інші чинники вимагають 
зведення процедур процесу оборонного планування в логічно вибудовану функціональну модель.

Така модель може представляти логічну послідовність виконання процедур та їх елементів, що дасть змогу визначити порядок використання вихідних даних однієї процедури, як вхідні дані для наступної, включаючи зворотні зв'язки та паралельну роботу в рамках виконання двох і більше процедурних елементів однісї або більше процедур одночасно.

Побудова сучасної моделі вітчизняного оборонного планування, має базуватися на методології планування на основі спроможностей, яка пройшла апробацію в державах-членах НАТО i визнана експертами найперспективнішою в оборонному плануванні.

У цій роботі побудова функціональної моделі процесу оборонного планування опирається, насамперед, на законодавче закріплення оборонного планування, напрацьований науково-методичний апарат $\mathrm{i}$ набутий досвід вітчизняної та іноземної практики реалізації цього процесу $[10,11]$.

Упродовж 2014-2019 pp. у МO i 3С України розроблено та прийнято низку нормативно-правових актів i методичних рекомендацій щодо удосконалення оборонного планування.

Результати аналізу методів планування та методології аналітичних процесів і процедур, які реалізовані в оборонному плануванні державчленів НАТО, свідчать, що найефективнішим і поширеним $\epsilon$ метод оборонного планування на основі спроможностей (ОПОС), однією 3 найважливіших складових якого $є$ оцінювання спроможностей.

3 огляду на ці та інші аргументи, саме оновлена система оборонного планування має базуватися на методі оборонного планування на основі спроможностей в складових сил оборони, як найдосконалішому і прийнятному в умовах українських реалій створення $\mathrm{i}$ розвитку оборонних спроможностей.

Нині держави-члени Альянсу реалізують таку систему оборонного планування на основі спроможностей. До того ж слід зазначити, що кожна країна Альянсу має власну систему оборонного планування, на організацію та здійснення якого впливають: характерні риси національного економічного устрою; особливості законодавства; відмінності в структурі збройних сил; прийнята в державі система прогнозування та планування іiі розвитку; умови, в яких здійснюється планування; національні традиції тощо. Наявність власних національних планів розвитку збройних сил потребує їх гармонізації (інтегрування) 3 відповідними планами НАТО та обов'язкового врахування (дотримання) принципів і стандартів Альянсу.

Отже, з огляду на досвід наших зарубіжних партнерів, в Україні є всі підстави і необхідні умови для створення функціональної моделі ОПОС, яка б враховувала національні особливості законодавства, ресурсні можливості держави, була адаптована до державного стратегічного планування та планування у сферах безпеки і оборони. Водночас вона має базуватися на загальних принципах і стандартах оборонного планування НАТО.

Варіант функціональної моделі процесу ОПОС, яка найбільше враховує зазначені аргументи i чинники, представлена у вигляді структурної блок-схеми функціональної моделі процесу оборонного планування (рис. 1) та стислого опису логічної послідовності проведення процедур процесу планування.

Слід зазначити, що побудова цієї функціональної моделі процесу оборонного планування здійснюється за класичною методологією, яка включає такі складові: мету здійснення процесу ОП і мету створення моделі; вхідні дані, необхідні для організації і здійснення процесу моделювання ОП; нормативну й законодавчу базу, в рамках якої протікає процес; опис (формалізацію) базових процедур; кінцевий результат процесу (вихід).

Метою ОП загалом $є$ забезпечення обороноздатності держави через визначення пріоритетів і напрямів розвитку сил оборони, їх спроможностей, озброєння та військової техніки, інфраструктури, підготовки військ (сил), а також розроблення відповідних концепцій, програм i планів 3 урахуванням реальних і потенційних загроз у воєнній сфері та фінансово-економічних можливостей держави $[10,11]$.

Метою створення функиіональної моделі є систематизація досліджень у сфері удосконалення методології оборонного планування; зокрема, відображення наочно (візуально) і проєктування їі функціонування за допомогою моделі, під якою розуміється теоретично вибудована сукупність уявлень про те, як виглядає система планування , як вона впливає на об'єкти управління, як адаптується до змін зовнішнього і внутрішнього середовища, щоб керована організація могла досягати поставлених цілей, забезпечувати свою життєздатність і постійно розвиватися. 


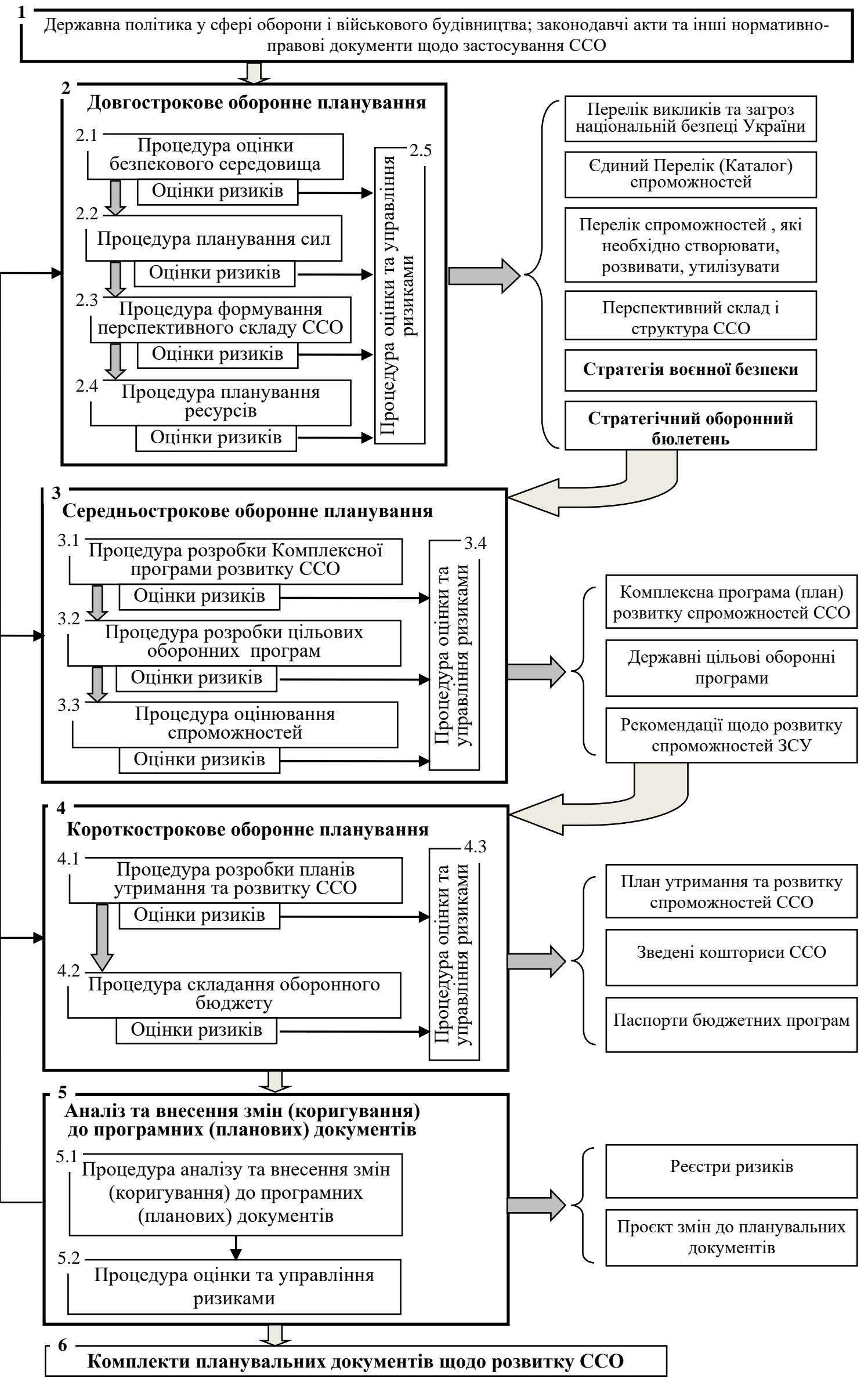

Рис. 1. Функціональна модель процесу оборонного планування 
Модель планування має включати в себе базові принципи менеджменту, стратегічне бачення, цільові установки і завдання, структуру i порядок взаємодії елементів, аналітичний моніторинг та контроль за ситуацією, рушійні сили розвитку та мотиваційну політику.

Вихідними даними (входом) для оборонного планування (моделювання процесу ОП) $є$ :

визначені законами України засади внутрішньої і зовнішньої політики, зокрема у сфері оборони держави;

визначені Президентом України стратегічні цілі та основні завдання політики національної безпеки у сфері оборони держави та уточнені, за необхідності, завдання сил оборони;

висновки за результатами аналізу досягнень воєнної науки та новітніх технологій військового та подвійного призначення;

визначені міжнародними договорами України зобов'язання у сфері контролю над озброєннями;

орієнтовні основні показники можливостей держави щодо задоволення потреб сил оборони людськими, фінансовими, матеріально-технічними та іншими ресурсами (поз. 1 на рис. 1).

У запропонованій моделі ОПОС базові процедури згруповані за видами планування (довгострокове, середньострокове та короткострокове) та визначена їх логічна послідовність відпрацювання. У ній також знайшли відображення процедури поточного оцінювання спроможностей, бюджетного планування, аналізу та внесення змін (коригування) до програмних (планових) документів та інтегрованої системи управління ризиками (рис. 1).

Під час довгострокового планування, вихідною позицією якого є оборонний огляд, передбачається проведення таких процедур, як оцінка безпекового середовища; планування сил; визначення перспективного складу військ (сил); планування ресурсів, а також оцінювання та управління ризиками (поз. 2 на рис. 1). За результатами виконання цих процедур формуються інформаційноаналітичні матеріали оборонного огляду, висновки 3 яких надалі використовуються у відповідних вихідних документах.

Під час довгострокового планування мають бути визначені фінансово-економічні можливості держави щодо прогнозних показників видатків Державного бюджету на довгострокову перспективу, що $\epsilon$ підтвердженням зв'язку оборонного планування 3 бюджетним планування та врахування ресурсних можливостей держави. Ці показники мають бути затвердженими відповідним актом Уряду.

Слід зазначити, що надалі напрацьовані інформаційно-аналітичні матеріали використовуються для розроблення стратегічних документів національного рівня, зокрема Стратегії воєнної безпеки України, Стратегічного оборонного бюлетеня.

Процедура планування сил у запропонованій моделі (поз. 2.2 на рис. 1), спрямована на визначення та обгрунтування, обсягу завдань, до виконання яких мають бути готові (спроможні) 3С України та інші складові CO. До того ж формулюються умови, за визначеними сценаріями, застосування СО. Опис зазначених умов може бути оформлений як окремий документ, або як єдиний інформаційний матеріал опису сценаріїв.

За результатами виконання процедури планування сил визначаються необхідні спроможності, які повинен мати перспективний склад і структура складових $\mathrm{CO}$, та шляхи їх досягнення. До того ж визначаються спроможності, які необхідно створювати, розвивати, підтримувати чи позбавлятися.

Під час процедури планування сил формуються інформаційно-аналітичні матеріали, на основі яких відпрацьовуються вихідні документи. Положення цих та інших документів використовуватимуться під час виконання процедур щодо визначення перспективного складу та структури 3С України (складових С), планування ресурсів та розробленні середньострокових програм і короткострокових планів, а також під час бюджетного планування.

У межах процедури формування перспективного складу і структури ЗС України (складових СО) проводяться дослідження щодо визначення необхідного і наявного складу та формується перспективний склад і структура ЗС України (складових СО) (поз. 2.3 на рис. 1). Особливістю цієї процедури є те, що, разом 3 визначенням перспективного складу та структури 3С України (складових СО), необхідно здійснювати ії декомпозицію аж до розроблення організаційно-штатної структури кожної 3 військових частин і підрозділів, військових закладів тощо.

Процедура планування ресурсів передбачає реалізацію основ i принципів сучасного ресурсного менеджменту та застосування програмно-цільового методу 
планування щодо використання державних коштів (поз. 2.4 на рис. 1).

Ця методологія спрямована на визначення обсягу ресурсів для забезпечення набуття необхідних спроможностей, реалізації вибраної стратегії їх досягнення, а відповідно, i реагування на виклики та загрози 3 урахуванням динаміки їх змін у майбутньому.

Отже, можна стверджувати, що запропонований підхід забезпечує цілеспрямоване використання оборонних ресурсів; дає можливість зосередити обмежені кошти на вирішенні найбільш значимих проблемах забезпечення обороноздатності; убезпечує керівництво від прийняття необгрунтованих рішень щодо ресурсного менеджменту тощо.

За результатами зазначених процедурних заходів щодо планування ресурсів передбачається напрацювання інформаційно-аналітичних матеріалів, зокрема, інформаційної бази (масиву) даних, які сконцентровані у відповідних вихідних документах.

Реалізація процедур довгострокового планування дає змогу сформувати документи національного рівня, які визначають основи стратегічного керівництва забезпеченням обороноздатності на державному рівні, що відповідатиме аналогічним процесам оборонного планування у державахчленах Альянсу.

У рамках здійснення процедур середньострокового планування мають розроблятися: Комплексна програма (план) розвитку спроможностей $3 \mathrm{C}$ України та аналогічні програми (плани) в інших складових СО; цільові оборонні програми та проводитися поточне оцінювання спроможностей (поз. 3 на рис. 1). Здійснення цих процедур визначається як етап програмування у загальній методології ОПОС, що базується на результатах попереднього етапу реалізації оборонного планування. Під час їх реалізації визначаються програмні заходи щодо набуття необхідних спроможностей через вирішення (усунення) проблем/недоліків у досягненні відповідності між необхідними та існуючими спроможностями.

Результати виконання процедур середньострокового планування забезпечують підготовку основного комплекту програмних документів та реалізацію системного (комплексного) підходу щодо розвитку спроможностей. До того ж цільові оборонні програми залежно від мети, обсягу та складності програмних заходів можуть бути довгостроковими, середньостроковими, і навіть короткостроковими програмними документами.

Поточне оцінювання спроможностей, як основну аналітичну складову ОПОС у запропонованій моделі, представлено окремою процедурою в рамках середньострокового планування (поз. 3.3 на рис. 1). Це оцінювання має проводитися за окремо розробленою методологією, аналоги якої успішно випробувані в оборонному плануванню державчленів НАТО. Зазначена методологія характеризується оцінюванням спроможностей за їх функціональними групами, окремими спроможностями та групами спроможностей. Для управління цим процесом в органах військового управління доцільно створювати систему управлення оцінюванням і розвитком спроможностей. Подібна система існує у США та інших державах-членах НАТО як система управління вимогами.

У рамках здійснення короткострокового планування найбільш значимою процедурою $є$ розроблення Плану утримання та розвитку спроможностей 3С України (інших складових СО) (поз. 4 на рис. 1). Вона є універсальною, 3 погляду охоплення всіх заходів як розвитку, так i утримання спроможностей $3 \mathrm{C}$ України (складових СО). У цьому контексті процедурні заходи підготовки Плану утримання і розвитку спроможностей 3С України (інших складових CO) будуть характерними i для інших документів короткострокового планування.

Окремою складовою запропонованої моделі ОПОС $є$ процедура бюджетного планування у МО України (поз. 4.2 на рис. 1), яка має відповідати вимогам Бюджетного кодексу України. До того ж акцент зроблений на проведення аналізу фінансових показників потреб МО України (складових СО) відповідно до їх планових заходів утримання та розвитку спроможностей.

Опираючись на єдину законодавчу базу 3 питань короткострокового та бюджетного планування у MO України можна стверджувати, що зазначені процедури можуть бути прийнятними і для планування в інших складових СО.

Пропонується включення до системи ОПОС процедури аналізу та внесення змін (корегування) до програмних (планових) документів за результатами їх моніторингу, яка вважається важливим елементом моделі оборонного планування під час реалізації іiі вихідних документів (поз. 5 на рис. 1). 
Невід'ємною складовою моделі ОПОС $\epsilon$ система оцінювання та управління ризиками, яка $є$ комплексною i охоплює як кожну 3 процедур, так i весь процес оборонного планування (поз. 5.2 на рис. 1). Розглядаючи кожну $з$ процедур ОПОС у частині можливих ризиків можна визначитися 3 певними закономірностями щодо їх характеру, проявів, ступеню впливу, врахування та досягнення прийнятного рівня показників тощо. Водночас ця система включає в себе дві складові: підсистему оцінювання (передбачення та виявлення ризиків, визначення їх імовірних розмірів і наслідків) та підсистему управління ризиками (сукупність процедурних заходів щодо підготовки та реалізації адміністративних рішень для зменшення негативного впливу ризиків на результати оборонного планування).

За результатами реалізації заходів системи оцінювання та управління ризиками розробляється: План заходів щодо управління ризиками процесу оборонного планування та підсумковий інформаційно-аналітичний документ Реєстр ризиків. Забезпечення функціонування системи оцінювання та управління ризиками процесу ОПОС має бути відповідальністю органів управління або окремих посадових осіб, які визначені відповідальними за організацію і проведення ОПОС, і здійснюється протягом всього його процесу. Відповідальним за забезпечення функціонування системи оцінювання та управління ризиками процесу ОПОС призначається визначений орган управління або окрема посадова особа, яка $\epsilon$ відповідальною за організацію і проведення ОПОС загалом.

Підсумковим елементом моделі ОПОС $\epsilon$ комплект опрацьованих документів планування, які спрямовані на розвиток спроможностей 3С України та інших складових СО (поз. 5.2 на рис. 1).

Загалом кінцевим результатом оборонного планування є очікуваний ступінь досягнення визначених показників розвитку спроможностей $3 \mathrm{C}$ та інших ССО.

Висновки. Узагальнення та аналіз розроблених основ побудови функціональної моделі процесу оборонного планування в складових сил оборони дає змогу дійти таких висновків:

запропонована функціональна модель $\epsilon$ логічною послідовністю виконання процедур та їх елементів оборонного планування, враховує сучасні принципи і підходи, які характерні для планування у державах-членах HATO;

реалізація розробленої функціональної моделі забезпечить повноту проведення оборонного планування, зокрема, аналітичних процесів оборонного огляду та оцінювання спроможностей, а також розроблення проєктів Стратегії воєнної безпеки України, Стратегічного оборонного бюлетеня України, програм і планів розвитку спроможностей складових сил оборони тощо;

запропонована у моделі процедура аналізу та внесення змін (корегування) до програмних (планових) документів за результатами їх моніторингу сприятиме підвищенню результативності програм та планів оборонного планування, що покращить його якісні показники.

Отже, представлена модель ОПОС, $\epsilon$ науково обгрунтованим фактором удосконалення національного оборонного планування, a iii реалізація буде підтвердженням застосування методології, яка орієнтована на методи і принципи оборонного планування НАТО та враховує національні особливості України.

\section{СПИСОК ВИКОРИСТАНОЇ ЛІТЕРАТУРИ}

1. Закон України "Про національну безпеку України” від 21 червня 2018 року № 2469-VIII // Відомості Верховної Ради України. - 2018.

2. Указ Президента України від 6 червня 2016 року № 240/2016 “Про рішення Ради національної безпеки і оборони України від 20 травня 2016 року “Про стратегічний оборонний бюлетень України".

3. Рекомендації з оборонного планування на основі спроможностей в Міністерстві оборони та Збройних Силах України, затверджені Міністром оборони України 13.06.2017 р. № 5789/3/3.

4. Рекомендації 3 порядку організації проведення оцінювання спроможностей у Збройних Силах України, затверджені Міністром оборони України 07.12.2017 p.

5. Крикун П. М., Павленко В. І., Кравчук В. В. Розвиток оборонного планування як складової національної системи планування у сфері безпеки та оборони за умов наближення до процедур i стандартів НАТО. // Збірник наукових праць ЦВСД НУОУ. - К., 2017. - № 2 (60) . - С. 44-48.

6. Сектор безпеки i оборони: стратегічне планування / $\quad$ В. Ф. Саганюк, М. М. Лобко, О. В. Устименко, А. К. Павліковський; за ред.. Р. І. Тимошенка. - К.: Майстер книг, 2016. - 148 с. 7. Дєнєжкін М. М., Наливайко А. Д., Поляєв А. І. Особливості оборонного планування у державахчленах НАТО, на основі спроможностей. // Збірник наукових праць ЦВСД НУОУ. - К., 2017. - № 2 (60) . - С. 34-38.

8.Крикун П. М., Павленко В. І., Полякова О. В. Алгоритм безпеки. // Оборонний вісник. Центр 
воєнної політики та політики безпеки, К., - № 2, 2018. - № 2. - С. 4-7.

9. Корендович В. С., Наливайко А. Д., Поляєв А. І. Підходи до створення та функціонування системи управління вимогами щодо розвитку спроможностей в органах управління складових сил оборони. // Збірник наукових праць ЦВСД
НУОУ імені Івана Черняховського". - К., 2018. № 1 (62). - C. 51-56.

10. "Is it Time to Bring Back Threat-Based Planning?", Major Tony Balaseviciucs, The Makenzie Institute (Canada), Security Matters, Spring 2016;

11. Capability-Based Planning and the Death of Military Strategy, Colonel Michael W. Pietrucha, U.S. Naval Institute, August 5, 2015.

Стаття надійшла до редакційної колегії 05.08.2019

Наливайко А. Д., канд. техн. наук, доцент ${ }^{1}$;

Поляев А. И. ${ }^{1}$;

Наливайко Л. П. ${ }^{2}$

1 - Центр военно-стратегических исследований Национального университета обороны Украины имени Ивана Черняховского, Киев;

2 - Научно-методический центр организации научной и научно-технической деятельности Национального университета обороны Украины имени Ивана Черняховского, Киев

Теоретические основы построения функциональной модели процесса военного планирования составляющих сил обороны

Резюме. В статье на основе анализа процедур процесса оборонного планирования составляющих сил обороны в контексте перспектив развития национального оборонного планирования, рассмотрены теоретические основы построения функциональной модели процесса оборонного планирования с учетом методов планирования, применяемых в государствах-членах НАТО.

Ключевые слова: оборонное планирование на основе возможностей; процедуры оборонного планирования; модель оборонного планирования.

\section{A. Nalyvayko, PhD (Technical)., associate professor ${ }^{1}$;}

\section{A. Polyayev ${ }^{1}$;}

L. Nalivayko ${ }^{2}$

${ }^{1}$ - Center for Military and Strategic Studies of the National Defence University of Ukraine named after Ivan Cherniakhovskyi, Kyiv

2 - Scientific-methodical center of organization of scientific and scientific-technical activity of Ivan Chernyakhovsky National University of Defense of Ukraine, Kyiv.

Theoretical foundations for building a functional model of the defense planning process in the constituent forces of the defense

Resume. In the article, on the basis of the analysis of the defense planning process of the components of the defense forces, in the context of the prospects of development of national defense planning, theoretical bases of construction of the functional model of the defense planning process are considered, taking into account the planning methods used in NATO member states.

Keywords: capabilities-based defense planning; defense planning procedures; defense planning model. 